\title{
13. Increasing the Resilience of China's Financial Sector and the Global Monetary System
}

Wing Thye Woo

\section{Pursuing sustained modern economic growth}

China entered the middle-income country category in 2006 according to Woo's (2012) Catch-Up Index (CUI), which is the ratio of a country's per capita GDP to US per capita GDP, with both measured in purchasing power parity (PPP) units. In Woo's classification, middle-income status begins with CUI at 20 per cent and high income begins at 55 per cent.

Continued fast progress by China to high-income status cannot be taken for granted. Four of the five largest economies in Latin American-Argentina, Brazil, Chile and Mexico - have been in the middle-income category since at least 1960. Furthermore, the secular decline in the CUI value of Venezuela, the fifth member, from its petroleum-induced high-income status, pushed Venezuela down into middle-income status in 1980. And Malaysia is a closer and more recent warning about the middle-income trap (Woo 2011). In Malaysia, after having been hailed in 1993 by the World Bank (1993) as an East Asian 'miracle' economy, catch-up growth stopped in 1995.

These large Latin American economies and Malaysia are no longer experiencing what Simon Kuznets (1971) called 'modern economic growth' (MEG). MEG is the type of economic growth that began in Western Europe in the late eighteenth century. It is distinguished from earlier types of growth by several qualities: a sustained high growth rate in per capita output, large shifts in the composition of output, increasing diversity in goods and services produced, and rapid institutional and ideological adjustments. Because the quintessential feature of MEG is continual change across many dimensions of society, the policy implication is that a country must change its economic policies after reaching each new stage of economic development in order to facilitate the continuation of growth.

Our research on economic growth in other countries has led us to the conclusion that China's successful economic transition from middle-income to high-income country cannot be achieved by the present dualistic policy regime of state-led industrialisation facilitated by state-directed allocation of capital, 
and enthusiastic private sector participation (mostly) in light industries and in the low and medium value-added portions of the service sector. The Soviet Union achieved middle-income status without private sector participation, but it ended in political and economic collapse in 1991. The achievement of middleincome status in Malaysia (with a Chinese-style policy regime of state-private dualism) has been followed by economic stagnation because of policy inaction caused by the government's short-sighted attitude of 'if it ain't broke, don't fix it'.

China has now reached the stage at which reform of its financial sector is among the urgently needed fundamental policy changes it must make in order to avoid falling into the middle-income trap. Continued inaction on comprehensive financial reform would spell the end of the latest of its attempts in the past 200 years to reach the productivity and living standards of the advanced economies.

\section{The financial sector reform agenda}

Most of the studies on the progress of financial development in China use an array of stock-flow ratios like the M2 to GDP ratio and the stock market capitalisation to GDP ratio. As the M2 to GDP ratio has increased from 124 per cent in 1998 to 188 per cent in 2010, and the capitalisation of the Shanghai and Shenzhen stock markets has climbed from an average of 30 per cent of GDP in 1997-2005 to 53 per cent in 2006-12, it is common for many China analysts to report steady progress in the country's financial development.

Two recent studies have, however, suggested that this steady upward march of the stock-flow ratios like M2-GDP hides some unfavourable trends in China's financial sector that could trigger a financial collapse (Liu and Qin (2014); Arcand (2014)).

Liu and Qin (2014) challenge the conventional view that there has been progress (albeit, insufficient) in China's financial development. They develop a price-based indicator instead of using the usual quantity-based indicator to measure the degree of structural friction in China's banking system. Their new indicator is called the 'shadow-minus-actual spread' (SAS) because this is the difference between the shadow interest rate and the actual interest rate.

To estimate the actual average interest rate (from the banking data on loans) and the shadow interest rate (from the composition of investment undertaken), Liu and Qin (2014) divide borrowers into two categories. 
1. low-risk enterprises (LREs), which correspond with state-owned and shareholding enterprises (including shareholding and limited-liability enterprises, mostly state-controlled).

2. high-risk enterprises (HREs), which correspond with private, self-employed individuals, collective-owned (most of which are in fact private-owned township and village enterprises) and other categories of enterprises. ${ }^{1}$

Liu and Qin calculate the average return rate on bank loans, r, as Equation 13.1.

Equation 13.1

$\mathrm{r}=w_{L R E} \mathrm{r}_{L R E}+w_{H R E} \mathrm{r}_{H R E}$

In Equation 13.1, $w_{L R E}$ and $w_{H R E}$ are the shares of the bank credit allocated to LREs and HREs respectively.

They calculate the shadow loan rate, $r^{\prime}$, as the average cost of funding the entire investment through bank loans (Equation 13.2).

Equation 13.2

$$
\mathrm{r}^{\prime}=v_{L R E} \mathrm{r}_{L R E}+v_{H R E} \mathrm{r}_{H R E}
$$

In Equation 13.2, $v_{L R E}$ and $v_{H R E}$ denote the investment share of LRE and HRE respectively.

The difference between the shadow loan rate and the actual loan rate, the shadow-minus-actual spread (SAS), is hence given by Equation 13.3.

\section{Equation 13.3}

$$
\mathrm{SAS}=\left(\mathrm{r}^{\prime}-\mathrm{r}\right)=\left(v_{H R E}-w_{H R E}\right)\left(\mathrm{r}_{H R E}-\mathrm{r}_{L R E}\right)
$$

Equation 13.3 suggests to us that the key assumption behind the SAS is that the actual composition of investment reflected the socially optimal proportion of high-risk projects and low-risk projects. If the risk preference of the banking system were identical to the risk preference of society, then the proportion of bank loans extended to high-risk projects would equal the proportion of highrisk investments chosen by society.

Our interpretation is in line with Liu and Qin's (2014) argument that if the banks were to price the risks of enterprises correctly and allocate credit resources according to economic criteria, the shares that LREs and HREs received in bank

1 There are two key differences between an LRE and an HRE. First, the state-owned enterprises (SOEs) and state-controlled enterprises (SCEs) have lower default risk because these firms face soft-budget constraints - that is, when the SOEs and SCEs are faced with bankruptcy, the Government tends to rescue them (through channels like fiscal subsidies) (Woo 1999). Second, the productivity of an LRE is far below that of an HRE (Woo et al. 1994). 
loans would roughly match their respective shares in investment spendingthat is, $v_{L R E}$ and $w_{L R E}$ will have the same values, and SAS would equal zero. When, however, the banking system tilts the allocation of loans towards LREs, then $v_{L R E}<w_{L R E^{\prime}}$ which implies that $v_{H R E}>w_{H R E}$. Liu and Qing call this bias by the banks towards making loans to the LREs the structural friction in the banking system. They find the disturbing result that the spread between the shadow rate of return and the actual rate of return on bank loans has widened over time, from 1.02 percentage points in 2003 to 2.38 in 2005, to 3.25 in 2007 and then to 3.76 in 2010. They identify two factors in the cause of the increasing inefficiency:

1. the disproportionate amount of bank loans allocated to state-controlled companies, making $\left(v_{H R E}-w_{\text {HRE }}\right)$ positive

2. the average productivity of the state-controlled companies being lower than the average productivity of domestic private companies, making $\left(r_{H R E}-r_{L R E}\right)$ bigger.

Arcand (2014) also shares Liu and Qin's assessment that China's financial sector has become more dysfunctional over time. In an earlier analysis of crosscountry data (Arcand et al. 2012), he found that an increase in a stock-flow ratio (for example, the M2-GDP ratio) when it is at a low value has a positive impact on economic growth, but there is a threshold value for the ratio beyond which an increase in the ratio will be harmful to economic growth. Specifically, this earlier study found that the marginal effect of financial development on economic growth becomes negative when credit to the private sector reaches 100 per cent of GDP.

In his more recent study, Arcand finds that this reversal from good effect to bad effect is generated in a simple model with endogenous default probability, credit rationing and bailout of state enterprises. The important point is that the presence of a bailout leads to a level of loans that is 'too large' with respect to the social optimum. When Arcand tests this model on Chinese data, he finds an empirical regularity that has hitherto gone unnoticed in the Chinese context: there is a large, negative and statistically significant impact from outstanding loans on the economic performance of provinces.

Financial reform is now clearly overdue. The most important requirement in the formulation of financial sector policy is recognition by the Chinese Government that the role of government in a middle-income country has to be substantially different from that of a government in a low-income country if dynamic catch-up growth is to continue. Specifically, the Chinese Government 
should now no longer focus primarily on raising funds cheaply to promote industrialisation because China is now a highly industrialised economy. The issue now is not the quantity but the quality of industrial expansion.

Furthermore, the fiscal position of the Chinese Government is now strong enough that it does not need to distort the financial sector in order to finance its support for industrialisation indirectly. Fiscal revenue has grown at an average 20 per cent per year since 2001, and fiscal revenue has climbed from 10.7 per cent of GDP in 1997 to more than 20 per cent of GDP in the past few years. The rapid appreciation of land prices has rendered the Government even more secure fiscally. The Government is now in a position to fund any promotion of industrialisation directly and so it should fund its industrialisation efforts directly and give up its direct intervention in the allocation of financial resources and to thereby reduce the economic cost of promoting industrialisation.

The time is right for a comprehensive reform of China's financial sector to help facilitate China's graduation from middle-income to high-income status. The four main sets of financial reforms that need to be undertaken are:

1. enlargement of the financial sector by diversifying the range of financial institutions and the range of financial assets, paying particular attention to the increase in equity issuance by private domestic firms

2. deregulation and modernisation of the banking sector

3. insertion of shock absorbers and circuit-breakers into the financial system to increase the resilience of the system against financial malfeasance and financial meltdowns, and to build up the financial firefighting capability of the regulatory agencies to minimise the costs of financial institution failure and to prevent financial contagion

4. updating the international dimensions of the financial sector consistently with the requirements of globalisation and China's emergence as a major economic power, and to enhance global monetary stability.

This chapter discusses the third and fourth of those sets of financial sector reform, focussing especially on steps that are necessary to avoid systemic financial collapse along the way to continuing modern economic growth. 


\section{Modernising the financial sector safely and bolstering financial firefighting capability}

The discussion of how to avoid systemic financial crisis can usefully begin with analysis of the recent financial collapses in a number of advanced economies, and proceed to drawing lessons for China and other developing countries, which are seeking to reform their financial sectors to support MEG. Three excellent articles on this topic have appeared recently: Sachs (2014); Boone and Johnson (2014); and Honkapohja (2014).

Sachs (2014) examines the record financial malfeasance in the United States in the past 30 years and finds that one of the features of the 2008 GFC was the epidemic of lawlessness among America's major investment banks, commercial banks, hedge funds, financial conglomerates and stock exchanges, collectively known as Wall Street. Major Wall Street firms have been repeated law-breakers, and as a result have faced dozens of lawsuits and criminal actions regarding corporate practices at the core of their business. The startlingly common aspect of these legal actions is that, with few exceptions, senior Wall Street managers have not faced personal costs as a result of corporate malfeasance. When settlements are reached with the US Securities and Exchange Commission (the Federal financial market regulator) on cases of financial malfeasance, the defendant's firm typically pays a fine but has been allowed to 'neither admit nor deny wrongdoing' (a practice that has been, correctly, criticised by Federal Court judge Jed Rakoff as not serving the public interest). The fine is often a small fraction of the gains that accrued to the company as a result of its malfeasant behaviour. With no judgment of guilt or acknowledgment or denial of wrongdoing, no further action is taken against senior management (for example, a revocation of a manager's right to engage in banking).

It is useful to examine the Jeffrey Sachs paper in some detail because most of the weaknesses that gave rise to the widespread financial malfeasance that he identifies exist in all capitalist economies to similar degrees. Sachs (2014) argues that there are five main structural reasons for the intrinsic proclivity of US financial institutions to engage in overly risky transactions:

1. the CEOs are inadequately supervised

2. the firms are highly leveraged operations

3. the compensation scheme for CEOs are based on value of equity

4. the financial industry is under-regulated

5. the political power of Wall Street in Washington DC is large. 
Large US companies have limited liability, are generally publicly owned and are characterised by highly dispersed shareholdings rather than ownership by a family or a small number of core investors. Because of the dispersed shareholding and limited liability, shareholders generally put little effort into monitoring corporate governance. The upshot is that CEOs have considerable authority with relatively low oversight from the board of directors, whose appointments are frequently made at the suggestion of management.

Banks tend to have an extremely high leverage ratio compared with nonfinancial corporations. A bank's job is to take on debt from depositors, other banks and the financial markets, to invest in assets. Using a simple numerical example, Sachs shows that high leverage increases the shareholder's appetite for risk beyond the social optimum if there is assymetry between the consequences of success and failure, with shareholders gaining a higher proportion of successes than of losses from failures. Leverage is encouraged by the presence of deposit insurance and by the implicit expectation of government bailouts of bank creditors in the event of a crisis. In the run-up to the GFC, US investment banks and European commercial banks had the highest leverage with a remarkable average of around 30 (total assets relative to equity). US commercial banks were less highly leveraged at around 10 - still very high compared with non-financial companies.

In Sachs' view, a major factor in the soaring compensation of CEOs in the past three decades was the increasing use of equity-based compensation, especially in the form of stock options. He extends his simple numerical example on leverage to clarify how stock options increase the CEO's appetite for risk beyond that of the shareholders. The combination of highly leveraged firms and CEO pay packages laden with stock options is strong motivation for a CEO to treat his enterprise as an enormous gamble for riches.

The process of financial deregulation started in earnest in the early 1980s in the savings and loan (S\&L) industry. Within a few years, the entire sector was bankrupt, in effect 'looted' by its CEOs (Akerlof and Romer 1993). Insolvent S\&Ls took advantage of federal deposit insurance to attract new deposits, and then used deposit inflows to make payments of phantom profits and other insider payments to the owner-managers of the S\&Ls. In the end, the Federal Government had to pay off the depositors, while many corrupt owners of bankrupt S\&Ls walked away with fortunes.

The culmination and most important act of deregulation was the GrammLeach-Bliley Act of 1999, which repealed the 1933 Glass-Steagall Act, a major part of the Great Depression's financial reform that separated deposit-taking activities and investment banking activities. Glass-Steagall was repealed in 1999 with strong bipartisan support. The leading architect of the repeal, Treasury 
Secretary Robert Rubin, immediately became chairman of Citigroup, a new financial conglomerate (formed in a US $\$ 140$ billion mega-merger of Citicorp and Travelers Group - one of the largest mergers in history) made possible by the deregulation.

Sachs (2014) attributes the extremely low personal risk of any penalties for financial malfeasance that senior Wall Street managers face and the steady deregulation of the financial industry to the enormous political power of Wall Street in Washington. The money flows mainly in two forms: as campaign contributions and as lobbying outlays, much of which end up in political pockets indirectly through hiring politicians into lobbying firms (and law firms).

More controversially, Sachs hypotheses that there has been a change in the moral Zeitgeist in the United States that has increased the acceptability of selfserving or illegal behaviour. He makes the case that super-high managerial compensation is not the social norm in rich capitalist countries, by citing the case of a leading and highly successful Swedish CEO, Percy Barnevik, who engineered a retirement package typical of a US CEO. When news of the retirement package became commonly known several years later, the public outcry forced the retired CEO to recant the arrangement and step down from other public positions. In the United States, however, the social restraints on high compensation packages have diminished, thereby making it easier for US CEOs to take the opportunity to increase their own pay cheques.

Based on his overview of Wall Street lawlessness, Sachs (2014) suggests the following seven areas as needing the greatest attention in trying to promote financial sector development safely.

1. Limit the leverage of financial institutions because it promotes excessive risk-taking or outright looting.

2. Implement tougher scrutiny and regulatory limits on compensation packages of CEOs, as in the European Union. Shareholders should have an automatic vote on compensation packages, and the use of stock options should be limited to avoid excessive risk-taking.

3. Increase significantly the higher levels of marginal taxation, in part to tamp down the incentives for managerial abuse.

4. Legislate for CEOs and senior managers to face personal liability for major acts of malfeasance committed by their companies during their watch. Personal liability could include the loss of licence to practice, forced resignation from office, a ban on bonuses and personal liability for a portion of corporate fines and civil settlements in cases where CEO responsibility or negligence can be determined. 
5. Bring criminal prosecutions against firms and individuals for large-scale financial malfeasance.

6. Bar Wall Street firms from lobbying activities and senior bank managers from making campaign contributions.

7. Undertake research on how to restore ethical norms on Wall Street.

Boone and Johnson (2014) investigate the roots of the systemic imprudence in the financial institutions of the developed countries. They show how prudent financial regulation, broadly defined, has proven difficult in wealthy nations. The economic incentives and political forces that promote undercapitalised financial institutions, over-leveraged production firms and unfinanced public entitlements have consistently and invariably won out over prudent management across Europe, the United States, Canada and Japan. This outcome has placed much of the wealthy world on a path lined with intermittent, but growing, financial crises. In particular, these countries are addicted to methods of economic management that are debt-financed (for example, recapitalising banks by issuing new government debt) because they have ageing populations, and future generations are not represented in the policymaking process.

Successive firm failures in financial crises are bailed out by the state, adding to deficits caused by ageing populations and limited political incentives to balance budgets. Rapid growth tends to obscure insolvencies. These difficulties usually surface only when growth turns down. Once large undercapitalised systems and structural budget deficits have developed, it is difficult to change course, leading to continued financial weakness and rising dangers. Inflation, financial repression and new crises follow from this systemic lack of prudence in wealthy nations.

While Boone and Johnson (2014) 'are skeptical that adequate changes can be achieved' in the developed economies 'without crisis', they see the possibility that rapidly growing economies (like China's) might be able to avoid the same outcome if they take the following three sets of actions now.

First, China must promote the safety of its financial institutions by:

1. enlisting the energy of creditors to monitor the financial institutions by passing strict no-bailout laws, which require creditor bail-in before public funds can be used

2. requiring financial institutions to have large buffers of equity and contingent capital

3. strengthening regulation by imposing multi-year restrictions on the participation of former financial regulators in private financial firms - that is, stopping revolving-door practices between the state and the private sector. 
Second, China must promote stable public finance by:

1. enforcing balanced budget rules through constitutional amendment (this requirement keeps current spending in check but cannot prevent overpromises on pensions)

2. implementing means test requirements for pensions because this would reduce the size of the group lobbying for high pensions at the expense of future generations

3. increasing transparency in the financial implications of fiscal actions - for example, there should be a nonpartisan agency (like the US Congressional Budget Office) that makes projections on the budget

4. instituting regular auditor-general reports and prosecuting malfeasance.

Third, China must recognise that financial bubbles usually cannot continue for extended periods without the complicity of the central bank. The US Federal Reserve under Alan Greenspan encouraged bubbles by giving implicit bailout guarantees to systemically important financial institutions (for example, through the interventions on Long Term Capital Management and Bear Stearns). It is therefore important to create an independent 'financial stability oversight board' to look over the shoulders of the central bank and the other financial regulators. The existence of this independent financial sector overseer will increase the emergence of whistle-blowers whose timely warnings will help prevent financial collapses.

Honkapohja (2014) identifies the reasons for the financial crises in Finland, Norway and Sweden in the 1980s by reviewing the process of liberalisation in the Nordic countries in that decade. He arrives at four key conclusions after discussing the reasons Finland, Norway and Sweden drifted into financial and economic crises.

The first conclusion is that the Nordic countries paid too much attention to the 'how to' and too little attention to 'what is'. There was a lot of attention on what would be the optimum sequencing of policy actions to dispense with the system of financial market and capital account controls. There was insufficient attention to: 1) how the different markets and production sectors would adjust to the policy actions; and 2) what conditions the banks and other market institutions were in. It was thought that firms and households would know how to adjust to the new system and would do so in a flexible way. However, it turned out that both banks and their customers moved towards the new equilibrium too rapidly, causing a credit boom, an asset price bubble and, in the end, a banking crisis. 
The Nordic countries did not realise clearly enough that liberalisation leads to increased risks and that behaviour needed to change in response. Prudential supervision did not have a significant role in the period of a controlled financial system, because the control mechanism by itself had substantially secured the stability of banks. How could the existing system of prudential supervision, which was not needed under the controlled system, have been counted on to start meeting its much heavier responsibilities right away upon financial deregulation?

It is important that all the parties involved understand the need to change ways of thinking and business practices. Traditional ways of thinking can become a trap. Market-based financial systems are inherently less controllable and thus market participants must prepare for new risks and uncertainties that were absent in a system of financial repression. Risk management and supervision become very important with financial deregulation.

Honkapohja's (2014) second conclusion was that strengthening the capital base of banks and reforming their supervisory systems are important requirements in advance of the major liberalisation steps.

The third conclusion was that the Nordic countries should have known that it would be difficult to maintain fixed exchange rates after they had moved to market-based financial systems and freed cross-border capital flows. The combination of free capital flows and a fixed exchange rate regime can generate immense speculative pressures, which make defence of the exchange rate costly.

The fourth conclusion is that it is important to try to time the main parts of the liberalisation so as to avoid a business-cycle upswing.

Honkapohja (2014) points out that the sheer size of China's economy makes its liberalisation process different from that of most countries. The reforms in China could have major spillover effects on other countries, and they might well take action in response to the Chinese reforms. China should therefore take into account in the planning of its financial deregulation the international repercussions of its financial sector reform and the possible foreign reactions to it.

To summarise, these three papers by Sachs (2014), Boone and Johnson (2014) and Honkapohja (2014) propose three sets of actions to modernise the financial sector safely and to bolster prudential oversight and financial firefighting capabilities. The first set seeks to reduce the incentives for and means of financial institutions and their managers engaging in excessive risk-taking by:

1. requiring the Government to prosecute financial institutions for financial malfeasance, and to make their managers bear personal liability for illegal acts by their firms 
2. replacing bailouts of creditors and stockholders with bail-ins

3. increasing the buffer of capital requirements

4. reducing the leverage ratios of financial institutions, and the use of equitybased compensation for their managers.

The second set of reforms is to change the cosy, self-serving relationship between the financial industry and the political establishment by:

1. limiting the amount the financial industry can spend on political donations

2. stopping the revolving-door employment patterns between Wall Street and Pennsylvania Avenue by putting multi-year delays in moving from employment in one of these two places to employment in the other.

The third set of reforms is to strengthen the regulatory capability of the state financial agencies, and to limit the ability of the central bank and fiscal authorities to destabilise the macro-economy by:

1. establishing an independent systemic financial stability oversight board to audit the conduct of monetary policy by the central bank to: 1) end the practice of the 'Greenspan put' (policy to guarantee against stock market collapse) to protect the culprits of irrational exuberance; 2) prevent the bias towards the defence of an overvalued currency; 3) audit the work of the financial agencies in approving new financial instruments and in prosecution of financial fraud; and 4) monitor the readiness of the slew of federal financial agencies to handle the orderly restructuring of failed financial institutions and to prevent financial contagion within and across countries

2. passing a law to stop the bias towards debt-financed state spending by: 1) requiring the federal budget be balanced over the business cycle; and 2) establishing an independent fiscal mediation board to craft overall expenditure-revenue reconciliation.

\section{Updating the international dimensions of financial policy}

China is now the second-largest economy in the world and is projected to become the largest soon. China's growth has already brought a significant change in the international division of labour, as exemplified by the relative decline of the developed world's manufacturing sector. The changing balance in international economic power and the increased interdependence amongst nations should also bring about large shifts in the economic architecture of the world - for example, the emergence of new forms of Asian economic integration, 
amendments to the governance of international financial institutions like the International Monetary Fund and the World Bank-and new international initiatives on the regulation of capital flows, and financial sector supervision in order to strengthen the stability of the international monetary system.

To be in line with the large structural changes in the Chinese economy and to enhance the efficiency and stability of the new global economic order, it is necessary that China's exchange rate regime be changed to accommodate the structural changes and to promote global systemic resilience. Three analytically useful articles on this topic have became available recently: Wu et al. (2014); Pan et al. (2014); and Woo (2014).

Wu et al. (2014) identify the medium and long-term choices for the renminbi exchange rate regime. For the medium term, they recommend that China implements exchange rate management with the characteristics of 'basket, band and crawl' (BBC). Specifically, they suggest setting up a dynamic target zone for management of the effective exchange rate where the central parity rate (based on the Balassa-Samuelson hypothesis about relative labour productivity growth) maintains an annual 2 per cent appreciation in terms of the real effective exchange rate, with the width of the target zone set to allow $+/-5$ per cent fluctuation for the movements of the renminbi exchange rate around the central exchange rate. For the long term, they recommend China implements a monetary regime that combines a floating exchange rate system and generalised inflation targeting.

In line with China's growing impact on the world economy, it is natural for the renminbi (RMB) to become an international currency - a currency that is used to denominate the prices of goods and financial assets traded among foreign countries. Pan et al. (2014) believe that against the background of the centre of gravity of the global economy moving towards Asia and a multi-polar global economy being formed, there should be movement towards a multiple reserve currencies system that has an internal stabilising mechanism. RMB internationalisation is an integral component of this reform package. Wu et al. (2014) suggest that RMB internationalisation proceeds in two phases. In the early phase, the key task is to transform the Chinese economy and the financial system and foster international demand for the renminbi. In the later phase, the task is to open the capital account and increase substantially the supply of renminbi for global use.

Reform measures to promote financial openness include issuing licences to foreign financial institutions to conduct RMB-denominated business, and allowing mergers with and acquisition of branches from state-owned banks. It is desirable to pursue policies that favour capital outflow to provide incentives for large enterprises and financial institutions to go overseas. 
To Woo (2014), the most important international aspects of China's financial reform are not whether or when the renminbi will be internationalised, or whether and when Shanghai should be allowed to become an international financial centre (IFC). He points out that once China's capital account is open like that of Taiwan, as it inevitably will be, the renminbi will automatically be internationalised like the Swedish krona and the Swiss franc, because foreigners could use it freely. Shanghai would automatically become an IFC like Stockholm and Geneva because foreign residents would be able to participate in China's stock and bond markets, and the Shanghai branches of foreign banks would be able to operate in any currency.

Woo (2014) identifies two fundamental international consequences of China's financial reform. First, the renminbi would become an international vehicle currency (IVC) like the US dollar and the euro - that is, it would join the small subset of internationalised currencies that other countries commonly use to denominate the prices of their traded goods and to denominate the international loans amongst themselves. Second, Shanghai would become a first-tier IFC (1-IFC) like the two present members, London and New York, in which the value of transactions in each is a quantum level higher than in the other IFCs like Frankfurt and Tokyo.

The Chinese Government should see the IVC and 1-IFC objectives as worth pursuing. These two developments would benefit China, for example through the creation of a new high value-added financial service industry, and the lowering of costs in international transactions. They would also bring large benefits to the world, increasing the supply of a basic global public good. The emergence of the renminbi as an IVC would help meet global demand for international reserves and for diversification of reserves. This would strengthen global financial stability by addressing an important systemic confidence problem.

In the present global monetary system in which the US dollar is the primary global reserve currency, there is a non-sustainable balance between the need for additional global liquidity to accommodate the growth of the international economy and the requirement for confidence in the US dollar as the global reserve currency. The larger the amount of US dollars held by non-US businesses and foreign governments, the greater is their concern about the ability of the US Government to maintain the purchasing power of the US dollar. (This presentday balance is not identical to the Triffin dilemma.) ${ }^{2}$ The availability of the renminbi as another major store of value that is available for easy use as an international medium of exchange reduces global dependence on the ability

2 Triffin (1960) had expressed scepticism about the continued ability of the United States over time to swap gold for US dollars freely, as required by the Bretton Woods monetary system. 
of a single central bank - the US Federal Reserve - to avoid mistakes in the conduct of monetary policy. It therefore increases international confidence in the resilience of the global monetary system.

\section{Concluding remarks}

Financial sector reform is of fundamental importance to the continuation of modern economic growth in China. It is important that China takes careful note of international experience with financial instability.

The fact that the developed economies have yet to produce a financial system that is absolutely safe to use should not be allowed to justify delaying the restructuring of China's financial industry. The key is to study foreign experiences carefully and to think critically about how the foreign lessons on building an efficient financial sector safely should be modified to take China's circumstances into account. This book contributes to that task. It is a lesson of experience that prudential measures should be taken both to prevent financial failures with effective monitoring and appropriate regulation, and also to facilitate the fighting of the financial fires that are still likely to ignite from time to time.

This concern for safety during financial transition is most strongly seen in the Chinese debate on whether, when and how the capital account should be opened. The concern is that capital account liberalisation could bring financial risks in two parts:

- excessive foreign capital inflows that cause asset bubbles and inflation

- an abrupt sudden reversal of the foreign capital flow that causes panic in domestic capital into joining the flight, and thus precipitate the collapse of the renminbi and financial system, and trigger a cessation of normal trade credit, and cause additional output decline.

These are valid concerns. However, the potential cost of financial openness has to be compared with the large benefits of financial openness. There is no way to eliminate the possibility of this disaster but actions can be taken to minimise the probability of it occurring (for example, requirements of large capital buffers and low leverage ratios), and actions to facilitate rapid control of the disaster and expeditious rebuilding afterwards.

The view that the capital account should not be opened until effective financial monitoring and prudential regulation systems are in place is untenable. The realities are that: 
1. financial regulation is learned best in the classroom and in the marketplace. The recent establishment of the Shanghai Free Trade Zone (SFTZ) allows the emergence of an offshore international financial centre to give real-life training for China's financial regulators in recognising the signs of a developing financial storm and defusing the situation, and in handling efficiently the recapitalisation and reorganisation of failed financial institutions

2. a financial market is neither open permanently nor shut permanently. The degree of openness at any point in time is a policy choice at that time. A capital account once opened could always be partially closed temporarily without long-run adverse consequences if the closure is done for the right reasons - like stopping a financial panic.

When a financial disaster occurs, the most important action is to prevent oil from spreading. In a large financial crisis that is causing massive capital flight, the normal tools of management, like raising the interest rate to high levels and imposing macro-austerity, are usually ineffective.

Extraordinarily adverse financial market developments can be contained only with extraordinary state actions that break the general public's sense of panic about asset values and the economic future.

\section{References}

Akerlof, G. A. and Romer, P. M. (1993), 'Looting: the economic underworld of bankruptcy for profit', Brookings Papers on Economic Activity 24(2): 1-74.

Arcand, J.-L. (2014), 'Credit rationing, bank bailouts, and the deleterious impact of credit: evidence from China', in W. T. Woo, Y. Pan, J. D. Sachs and J. Qian (eds), Financial Systems at the Crossroads: Lessons for China, London: Imperial College Press \& World Scientific Press.

Arcand, J.-L., Berkes, E. and Panizza, U. (2012), Too much finance, IMF Working Paper WP/12/161, International Monetary Fund, Washington, DC.

Boone, P. and Johnson, S. (2014), 'Systemic lack of prudence in wealthy nations: avoiding the dark side of financial development', in W. T. Woo, Y. Pan, J. D. Sachs and J. Qian (eds), Financial Systems at the Crossroads: Lessons for China, London: Imperial College Press \& World Scientific Press.

Diaz-Alejandro, C. (1985), 'Good-bye financial repression, hello financial crash', Journal of Development Economics 19(1-2): 1-24. 
Honkapohja, S. (2014), 'Lessons from the financial liberalization in the Nordic countries in the 1980s', in W. T. Woo, Y. Pan, J. D. Sachs and J. Qian (eds), Financial Systems at the Crossroads: Lessons for China, London: Imperial College Press \& World Scientific Press.

Krugman, P. (2010a), 'Chinese New Year', The New York Times, 1 January 2010.

Krugman, P. (2010b), 'Taking on China', The New York Times, 15 March 2010.

Kuznet, S. (1971), Modern economic growth: findings and reflections, Lecture to the memory of Alfred Nobel, 11 December 1971. Available from $<$ http://www.nobelprize.org/nobel_prizes/economic-sciences/ laureates/1971/kuznetslecture.html $>$.

Liu, H. and Qin, T. (2014), 'The structural friction in China's banking system: causes, measurement and solutions', in W. T. Woo, Y. Pan, J. D. Sachs and J. Qian (eds), Financial Systems at the Crossroads: Lessons for China, London: Imperial College Press \& World Scientific Press.

Liu, L.-Y. and Woo, W. T. (1994), 'Saving behavior under imperfect financial markets and the current account consequences', Economic Journal 104(424): $512-27$.

Pan, Y., Xu, Y. and Wu, J. (2014), 'The internationalization of the renminbi in accordance with China's national interests and global responsibilities', in W. T. Woo, Y. Pan, J. D. Sachs and J. Qian (eds), Financial Systems at the Crossroads: Lessons for China, London: Imperial College Press \& World Scientific Press.

Sachs, J. D. (2014), 'Wall Street lawlessness', in W. T. Woo, Y. Pan, J. D. Sachs and J. Qian (eds), Financial Systems at the Crossroads: Lessons for China, London: Imperial College Press \& World Scientific Press.

The New York Times (2010a), 'Currency dispute likely to fray US-China ties', The New York Times, 4 February 2010.

The New York Times (2010b), 'Will China listen?', [Editorial], The New York Times, 17 March 2010.

Tobin, J. (1978), 'A proposal for international monetary reform', Eastern Economic Journal (July-October): 153-9.

Triffin, R. (1960), Gold and the Dollar Crisis: The Future of Convertibility, New Haven, Conn.: Yale University Press. 
Wolf, M. (2010), 'China and Germany unite to impose global deflation', The Financial Times, 16 March 2010.

Woo, W. T. (1999), 'The real reasons for China's growth', The China Journal, Volume 49: 115-37.

Woo, W. T. (2008), 'Understanding the sources of friction in U.S.-China trade relations: the exchange rate debate diverts attention away from optimum adjustment', Asian Economic Papers 7(3): 65-99.

Woo, W. T. (2011), Understanding the middle-income trap in economic development: the case of Malaysia, Invited World Economy Lecture delivered at the University of Nottingham, Globalization and Economic Policy Conference, Globalization Trends and Cycles: The Asian Experiences, Semenyih, Selangor, Malaysia, 13 January 2011. Available from <http://www.nottingham.ac.uk/gep/documents/lectures/world-economyasia-lectures/world-econ-asia-wing-thye-woo-2011.pdf $>$.

Woo, W. T. (2012), 'China meets the middle-income trap: the large potholes in the road to catching-up', Journal of Chinese Economic and Business Studies 10(4): 313-36.

Woo, W. T. (2014), The future of the renminbi as an international currency and Shanghai as an international financial centre, Working Paper, University of California at Davis.

Woo, W. T., Hai, W., Jin, Y. and Fan, G. (1994), 'How successful has Chinese enterprise reform been? Pitfalls in opposite biases and focus', Journal of Comparative Economics 18(3): 410-37.

Woo, W. T., Lu, M., Sachs, J. D. and Chen, Z. (eds) (2012), A New Economic Growth Engine for China: Escaping the Middle-Income Trap by Not Doing More of the Same, London: Imperial College Press \& World Scientific Press.

World Bank (1993), The East Asian Miracle: Economic Growth and Public Policy, Washington, DC: The World Bank.

Wu, X., Pan, Y., Zhang, Z., Nie, J. and Zhou, S. (2014), 'The options for reforming the renminbi exchange rate regime', in W. T. Woo, Y. Pan, J. D. Sachs and J. Qian (eds), Financial Systems at the Crossroads: Lessons for China, London: Imperial College Press \& World Scientific Press. 
This text taken from Deepening reform for China's long-term growth and development, edited by Ligang Song, Ross Garnaut, Cai Fang, published July 2014 by ANU Press, The Australian National University, Canberra, Australia. 